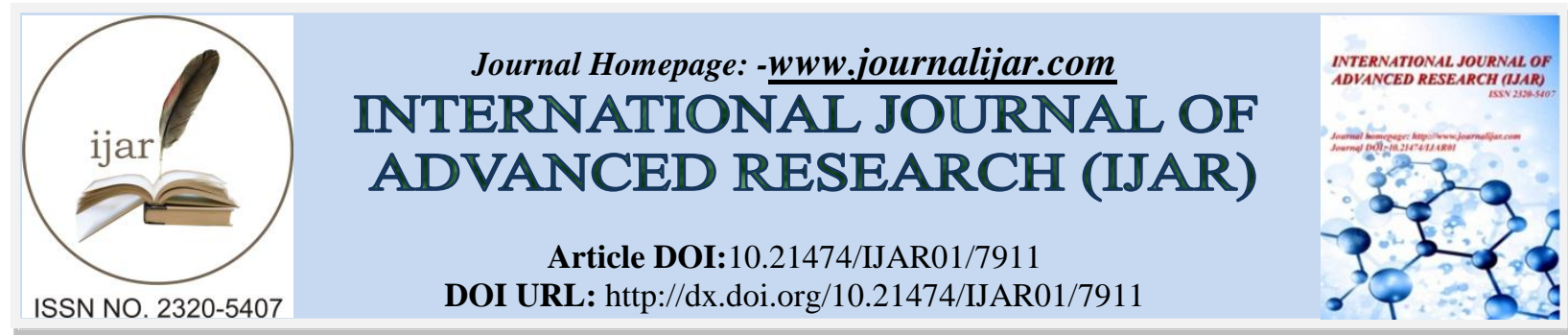

RESEARCH ARTICLE

\title{
THE EFFECT OF THE PRICE AND QUALITY OF SERVICE ON CUSTOMER SATISFACTION AND CONSUMER LOYALTY IN DCK.
}

Dr. Daniel Kurniawan.

Ciputra UniversityTeddy Saputra, S.E., M.B.A.Ciputra University.

\section{Manuscript Info}

\section{Manuscript History}

Received: 12 August 2018

Final Accepted: 14 September 2018

Published: October 2018

Keywords:-

price, service quality,
satisfaction, consumer
consumer loyalty, quantitative explanatory.

\section{Abstract}

The increase of public awareness in the importance of maintaining the well-designed homes and business places, causing a rise in the growth of production value of furniture sector belonging to small industries. DCK is one of those small furniture industries. This growth makes the competition among furniture businesses is also increasing. This is why this research is being done by the researchers. This study aims to identify and analyze the variables affecting marketing performance such as price, service quality, customer satisfaction, and customer loyalty.

Each of these variables is formed by several indicators where in price's variables, there are indicators such as flexibility, customization, differentiation, and promotion. While for service quality variables, there are tangible, reliability, assurance, responsiveness, and empathy indicators. For customer satisfaction, there are complaint, referral, repurchase likelihood. As for the loyalty of consumers, the variables are brand loyalty, consumer retention, and demand growth.

This research uses purposive sampling method to attain the sample. The sample in this study are all DCK consumers who buy DCK services with nominal minimum 15 million rupiah and above, and live in Surabaya, also who have bought DCK services at least a year ago. This research is also a type of quantitative explanatory where there is an explanation between the influences of the variables present in it.

The results of this study show that price and quality of service have a significant effect on customer satisfaction. In addition, in this study also indicated that consumer satisfaction has a significant effect on consumer loyalty.

Copy Right, IJAR, 2018,. All rights reserved.

\section{Introduction:-}

CV. Dharma Citra Kencana, that will be written DCK in this journal, has been established for 24 years. Initially, the focus of the services provided was the general contractor for the renovation of houses, offices, shops, storefronts and many others. However in its development, not only the renovation is done, but also this company has been able to build houses, factories, warehouses and other property types, from zero until it become a completed buildings. Even for now, DCK services have also extent its services into interior design, complete furniture making. 
Over time, people are increasingly aware of the importance of maintaining the good appearances of homes and places of businesses. That is why there are turnover and production amount of DCK that increasing from year to year. The Central Bureau of Statistics publishes an official report on the growth of production value of the furniture sector belonging to small industries, which in 2012 totaled 2.59 trillion rupiah, increasing to 20.2 trillion rupiah in 2013 (BPS, 2014). Therefore, the chance of DCK to continue in developing the business must be done. It is to maintain the trend of increasingly complex needs of the community related to the field of business.

Although DCK is experiencing high turnover growth, it does not necessarily bring gross margin increase for DCK. From the review of the existing data, in the last five years, the average increase by $25 \%$ per year in turnover. The increase in the speed of internet access since the last 5 years, has brought a new landscape competition, because consumers can easily and quickly assess, compare the price of design services of companies with one other company. The tight competition in the price between interior design company services and the increasing price of raw materials production, making the gross margin decreased. Every year the price of raw materials has increased significantly, causing the HPP (cost of goods sold) to be higher, and consequently gross margin obtained by DCK also decreased.

With the presence of more competitors in Surabaya, the price of services offered to the market is increasingly competitive, and sometimes DCK gets little profit margin to compete in the market. With this phenomenon, research is needed to determine whether the price of services offered to consumers has been in line with the target market segment. With the creation of the correct Price, it will increase the competitiveness of DCK compared to business competitors in the future. The competitiveness of a company is indicated "increasing" if the price of the product is no longer become the customer's main objection before making a purchase decision (Hawkins \& Mothersbaugh, 2011).

In addition, based on company data, about $50 \%$ of the total number of consumers is included in household segment (46 of 90 orders). This shows that the opportunity to improve the company's marketing performance in the future is still very big. In addition, there are also data comparing prices offered by DCK companies with several other competitors. That is one purpose of this research is running to assess the perception of consumers who have bought DCK services, whether the price of services purchased is the same with the wishes and expectations of consumers.

An important factor besides the price and quality of products that DCK consumers are looking for is the quality of service. Currently DCK still does not have a high and strong service standards, and still get criticism from consumers, especially related to the problem of delivery and installation of furniture on site. This research also aims to determine whether the quality of service affects the satisfaction of DCK consumers.

At this time, other problem in DCK is consumer satisfaction, because this factor is the way that the company differentiates itself compared to other companies. In general, consumers looking for a good quality products but on the other hand, the desired price is very low. Therefore, DCK can not only emphasize the price alone, but in terms of service quality and customer satisfaction, in order to convince consumers and make consumers continue to loyal and repeat to buy from time to time.

\section{Research Problems}

Based on the background that has been described, then the research problems created are:

1. Does Price Affect Consumer Satisfaction?

2. Does Service Quality Affect Consumer Satisfaction?

3. Does Consumer Satisfaction Affect Consumer Loyalty?

\section{Literature Review}

Singh (2013) conducted a study that aims to determine the impact of service quality on consumer loyalty. The population of this study is all major supermarket consumers in India. The sample of research taken is as many as 600 consumers, obtained from 7 large supermarkets coming from different districts in India. The research variables used are service quality, customer satisfaction and loyalty. The analysis used is descriptive statistic and one way ANOVA. The results showed that if the quality of service is considered well by showing a positive and significant results on consumer loyalty. 


\section{Consumer Loyalty}

Consumer loyalty is the expectation of each company, this is able to make the company survive for a long time. It is better to get consumers who buy not too much, but loyal for the long term, compared to consumers who buy products with large amounts but only for short-term course (Tetu, et al., 2013). Consumer loyalty can be created if the company has been able to provide quality products and services consistently and make consumers always satisfied from time to time.

The dimensions of consumer loyalty used in this study are the dimensions developed by Tetu, et al. (2013), namely Brand Loyalty, Consumer Retention, and Sales Increase. Here is an explanation for each of these dimensions:

1. Brand Loyalty: the degree to which a consumer is involved in a product brand or company name. This implies that a consumer who is loyal to a brand will not easily move his purchase to another brand, whatever happens with the brand.

2. Consumer Retention (Consumer Retention): the circumstances in which consumers want to keep in touch with the company on an ongoing basis.

3. Demand Growth: the degree to which consumers will repeat purchase more in the future.

\section{Consumer Satisfaction}

Consumer satisfaction and dissatisfaction has a function of increased disconfirmation of the difference between past expectations and current product performance (Rawson, et al., 2013). Satisfaction is a process of consumer evaluation where consumers act by comparing actual performance and performance expectation. Consumer satisfaction or dissatisfaction with the services offered at the time depends on the perceptions of existing performance and the perception of the gap between expectations and reality.

The dimensions or indicators of consumer satisfaction used in this study are the dimensions developed by Jayasankar \& Kumar (2012), namely Complaint, Referral, and Repurchase Likelihood. Here is an explanation for each of these dimensions:

1. Complaint: the degree to which the consumer is not satisfied with the quality of the product or service provided by the company. Indicators that contradict the consumer satisfaction are intentionally used for the company to understand directly what the actual satisfaction factor sought by consumers. The higher the degree of complaint, the lower the level of satisfaction those consumers perceive.

2. Referral: the degree to which consumers willingly refer associates or others to buy products from the same company, without being promised more incentives or benefits from the company.

3. Repurchase Likelihood: the degree to which the consumer has great potential to buy again the same product or different product from the same company in the future.

\section{Price}

Price is one element in the marketing mix that is able to generate revenue. While other marketing mix elements result in cost spending. Price is the most easily-modified element according to the market needs compared to other elements, such as product features, distribution channels, promotional programs that generally take longer to implement. Pricing to create a quality perception is the most favored by companies, because consumers tend to be more price-sensitive than other elements.

Price dimension used in this research refers to research conducted by Alptekinoglu \& Corbett (2012), that is flexibility, customization, differentiation, and price promotion. Here is an explanation for each of these dimensions:

1. Flexibility (flexibility): the price created from the way payment will be made by consumers. Consumers can choose whether the payment method is by term or cash. Companies may apply different prices for different payment methods.

2. Customization: it means that the pricing on one customer to another may differ depending on the type of quality and raw materials demanded to make the product, thus the consumer will think that the price of the product is relative, depending on the type of demand and their needs.

3. Differentiation : meaning that nthe price can also be created for all types of customers served, the amount of purchase volume, and when the order occurs.

4. Price Promotion: is one way of price creation that aims to increase the number of sales turnover in the short term. Price promotion is an effective strategy to influence consumer purchasing decisions immediately. 


\section{Quality of Service}

Consistency of the company in providing quality services, is the company's competence to fulfill the promise given to the consumer through the media campaign that is used. It is related and reflects the company's credibility in service issues. Good service deals with the conditions under which the company performs its functions to the maximum within a certain period of time, and under certain conditions. The success rate of the company to do business can also be judged from the responsiveness in immediately overcoming the failure professionally, then can create a positive perception of consumers on the quality of service, resulting in consumer confidence and confidence (Rust \& Huang, 2012).

The service quality dimension used in this study is the dimensions developed by Parasuraman in Chabbra (2013), namely Tangibles, Reliability, Responsiveness, Assurance, and Empathy. Here is an explanation for each of these dimensions:

1. Tangibles: the degree of the company's ability to demonstrate its existence to external parties. This capability is manifested in the appearance and capabilities of the company's physical facilities and infrastructure and the environment.

2. Reliability: the degree of ability of the company to provide services as promised accurately and reliably.

3. Responsiveness: the degree of the company's ability to help and provide quick and precise service to consumers, with clear information delivery.

4. Assurance: the degree of the company's ability to grow consumer confidence in the company.

5. Empathy: the degree of ability of a company to give a genuine and personal attention, given to the consumer by trying to understand the consumer's wishes one by one.

\section{Research Model}

Based on the background and the research problems, the following is a picture of this research model:

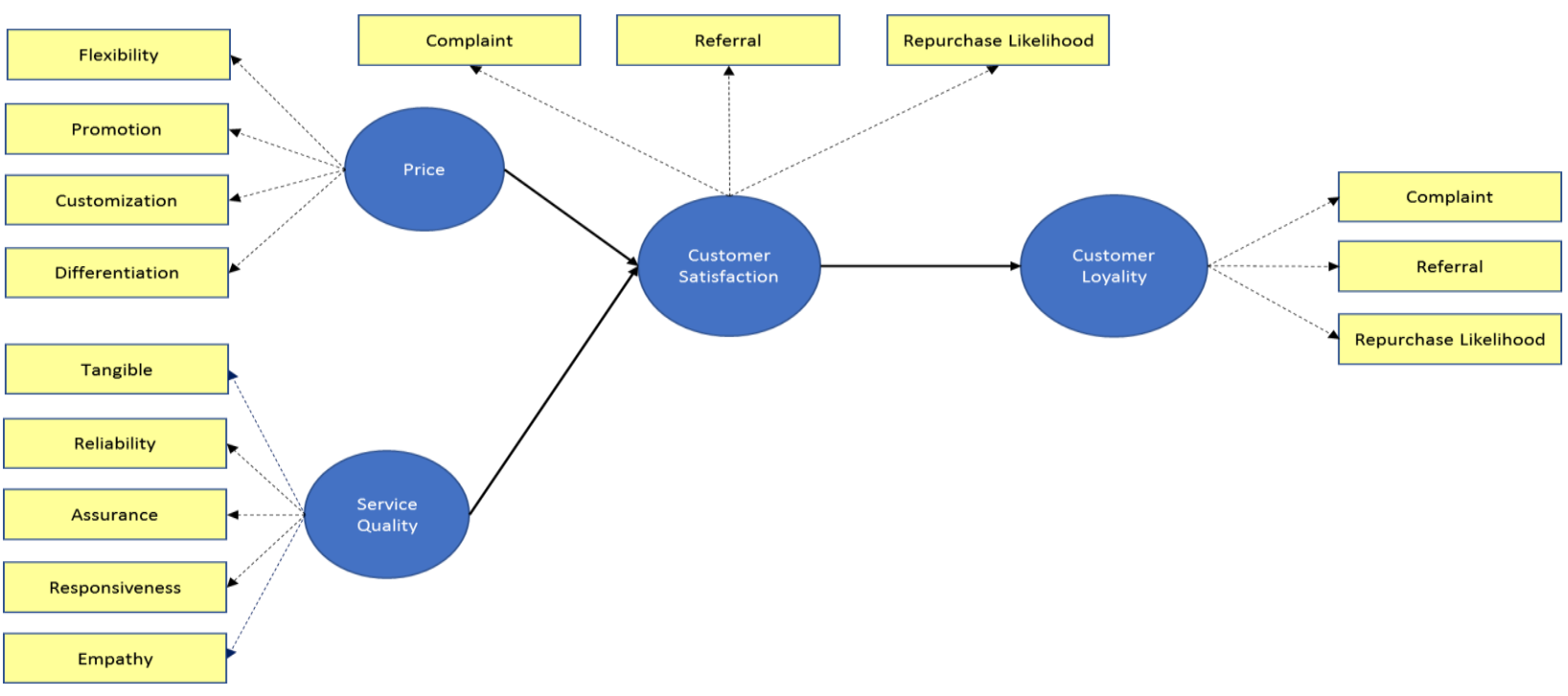

Figure 1:-Research Model

Information:

$\longrightarrow \quad:$ Hypothesis

\section{Hypothesis}

Based on literature review, theoretical study and conceptual framework, then prepared the research hypothesis as follows:

1. Price has a significant effect on customer satisfaction $(\mathrm{H} 1)$

2. Quality of service significantly influence consumer satisfaction $(\mathrm{H} 2)$

3. Consumer satisfaction has a significant effect on consumer loyalty $(\mathrm{H} 3)$ 


\section{Research Design}

This research uses quantitative approach so it takes some hypothesis that has been formed and tested from previous research. In the end the hypothesis shows a level of significance when analyzed with statistical tools. This study aims to analyze the causal relationship between independent variables, intermediate variables and variables dependent simultaneously in a model.

This research includes quantitative research, so the primary data is collected by distributing questionnaires to the predefined respondents then the data is processed by means of statistics in the research laboratory. The unit of analysis refers to the level of aggregation of data to be collected for research. This study uses an individual analysis unit. Time Horizon this study is data collected in one time only, perhaps in periods of days, weeks, or months aimed at answering research questions (Sekaran, 2010: 164).

Based on the classification, this research is included in the type of quantitative research. Quantitative research in this research is used for explanatory purposes, for example to explain the influence between variables or causal relationships between variables through hypothesis testing. Furthermore, because information or data on price, consumer satisfaction, and consumer loyalty is obtained based on views, responses, perceptions or assessments from DCK consumers, this research is also included in perception research, also referred to as opinion research.

The research place is in Surabaya and its surroundings, while the research time is during May - August 2014. Research respondents are the consumers who have purchased DCK services.

This research uses purposive sampling method to attract sample. The sampling criteria are: (1) buying DCK services with minimum nominal of 15 million rupiah and above, and (2) lives in Surabaya; (3) Have purchased DCK services at least a year ago (2013). The total population currently has 96 consumers. To determine the number of samples, used Slovin method whose formula as follows:

$$
n=\frac{N}{N \cdot d^{2}+1}
$$

Information:

$\mathrm{N}=$ minimum sample size

$\mathrm{N}=$ total population

$\mathrm{D}=$ confidence tolerance $(15 \%=0.15)$, a rule in the social sciences that maximal tolerance error can reach $25 \%$

(Gaston in Yamin, 2011; wikipedia statistic, 2014; researchgate.net, 2014).

By using Slovin method to draw the required number of samples, the population of 96 consumers $(\mathrm{N}=96)$ requires a sample of 30 consumers $(n=30)$. Therefore, a selection of 30 people will be selected, which will be sampled in the study.

The types of data used in this study are as follows: 1) nominal data, such as respondent's name, gender, purchase purpose of furniture products; 2) Ordinal data, such as respondents' educational background; 3) Interval data, ie all respondent's perception questions will be price variables, product quality, service quality, customer satisfaction and loyalty; 4) Data ratio, such as age of respondent, long to be a consumer, nominal purchase of products that have been done.

Sources of data used in this study there are 2 kinds, namely the primary data source, taken from the questionnaire answered by the respondents who will be collected in this study. Total respondents 30 consumers who have bought DCK services with nominal 15 million rupiah and above. While other data sources are secondary data sources for example data from government agencies such as BPS related to the sale of furniture regionally. This data serves as a reference development of market trends that occur.

Technique of collecting data is using a questionnaire method. After the questionnaire was made, then the respondent who had been contacted earlier to make an appointment, was given time to answer all questions in the questionnaire. Researchers will wait and provide the necessary explanation when filling questionnaires conducted by respondents. 
All indicators that make up the latent variables in this study use an interval scale that is an indicator that states something is abstract. Price variables, product quality, customer satisfaction, and customer loyalty in this study were measured using Likert scale or summated ratings method and the measurement result was data with interval scale.

The research instrument is a tool used to collect and process data. When developed by the researchers themselves, the instrument must be tested in order to achieve high reliability and validity. If the instrument used can be adapted to other instruments, the reliability and validity index of the adaptation results should be mentioned. Data processing instrument using Partial Least Square (PLS) method run by SmartPLS program. Similarly, data analysis, also using the PLS method. Here are the steps of analysis with Partial Least Square method:

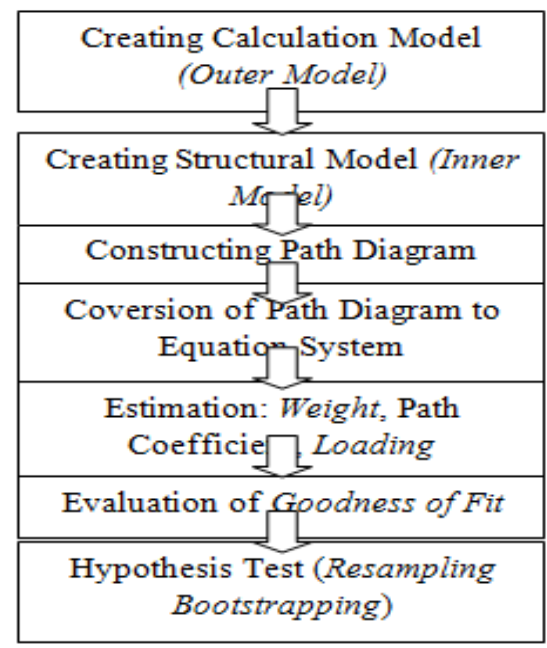

Figure 2:-Step in Analyzing Using PLS Source: Ferdinand (2011)

\section{Findings}

An indicator is valid if it has a loading factor above 0.7 to the intended construct. However, Hair et. Al. (2014) if the loading factor is above 0.4 , it still fine to maintain those indicators in order to keep the convergent validity. As shown in table bellow, the factor loadings from every indicators shown value above 0.4 :

Tabel 1:-Loading Factor Value

\begin{tabular}{|l|r|r|l|}
\hline Price Indicator & Outer Loading & SE & P value \\
\hline X.1.1.1 & 0.676 & 0.129 & $<0.001$ \\
\hline X1.1.2 & 0.675 & 0.129 & $<0.001$ \\
\hline X1.2.1 & 0.622 & 0.133 & $<0.001$ \\
\hline X1.2.2 & 0.571 & 0.136 & $<0.001$ \\
\hline X1.2.3 & 0.604 & 0.134 & $<0.001$ \\
\hline X1.3.1 & 0.587 & 0.135 & $<0.001$ \\
\hline X1.3.2 & 0.583 & 0.135 & $<0.001$ \\
\hline X1.4.1 & 0.761 & 0.124 & $<0.001$ \\
\hline X1.4.2 & Outer Loading & 0.125 & $<0.001$ \\
\hline Xervice quality Indicator & & SE & P value \\
\hline X2.1.1 & 0.495 & 0.141 & $<0.001$ \\
\hline X2.1.2 & 0.705 & 0.127 & $<0.001$ \\
\hline X2.3.1 & 0.785 & 0.122 & $<0.001$ \\
\hline X2.3.2 & 0.558 & 0.137 & $<0.001$ \\
\hline X2.4.1 & 0.731 & 0.126 & $<0.001$ \\
\hline X2.4.2 & 0.65 & 0.131 & $<0.001$ \\
\hline X2.5.1 & 0.629 & 0.132 & $<0.001$ \\
\hline X2.5.2 & 0.707 & 0.127 & $<0.001$ \\
\hline
\end{tabular}




\begin{tabular}{|c|c|c|c|}
\hline Customer Satiscation Indicator & Outer Loading & SE & P value \\
\hline Y1.1.1 & 0.707 & 0.127 & $<0.001$ \\
\hline Y1.1.2 & 0.771 & 0.123 & $<0.001$ \\
\hline Y1.1.3 & 0.813 & 0.121 & $<0.001$ \\
\hline Y1.2.1 & 0.769 & 0.123 & $<0.001$ \\
\hline Y1.2.2 & 0.451 & 0.144 & 0.002 \\
\hline Y1.3.1 & 0.879 & 0.117 & $<0.001$ \\
\hline Y1.3.2 & 0.887 & 0.116 & $<0.001$ \\
\hline Y1.3.3 & 0.868 & 0.118 & $<0.001$ \\
\hline Customer Loyality Indicator & Outer Loading & SE & P value \\
\hline Y2.1.1 & 0.829 & 0.12 & $<0.001$ \\
\hline Y2.1.2 & 0.558 & 0.137 & $<0.001$ \\
\hline Y2.2.1 & 0.65 & 0.131 & $<0.001$ \\
\hline Y2.2.2 & 0.469 & 0.143 & 0.001 \\
\hline Y2.3.1 & 0.837 & 0.119 & $<0.001$ \\
\hline Y2.3.2 & 0.843 & 0.119 & $<0.001$ \\
\hline
\end{tabular}

Furthermore, reflective indicators also need to be tested discriminant validity by cross loading as follows:

Tabel 2:- Cross-Loading Values

\begin{tabular}{|c|c|c|c|c|c|c|c|}
\hline & price & serqual & c_s & c_loyal & Type (a & SE & $P$ value \\
\hline X.1.1.1 & 0.676 & -0.193 & -0.267 & 0.048 & Reflect & 0.129 & $<0.001$ \\
\hline $\mathrm{X} 1.1 .2$ & 0.675 & 0.824 & -0.629 & 0.157 & Reflect & 0.129 & $<0.001$ \\
\hline $\mathrm{X} 1.2 .1$ & 0.622 & -0.143 & -0.063 & 0.003 & Reflect & 0.133 & $<0.001$ \\
\hline $\mathrm{X} 1.2 .2$ & 0.571 & 0.659 & -0.72 & 0.689 & Reflect & 0.136 & $<0.001$ \\
\hline $\mathrm{X} 1.2 .3$ & 0.604 & -0.435 & 0.195 & 0.176 & Reflect & 0.134 & $<0.001$ \\
\hline $\mathrm{X} 1.3 .1$ & 0.587 & -0.629 & 0.881 & -0.4 & Reflect & 0.135 & $<0.001$ \\
\hline $\mathrm{X} 1.3 .2$ & 0.583 & -0.651 & 0.304 & -0.294 & Reflect & 0.135 & $<0.001$ \\
\hline $\mathrm{X} 1.4 .1$ & 0.761 & 0.205 & 0.161 & -0.047 & Reflect & 0.124 & $<0.001$ \\
\hline $\mathrm{X} 1.4 .2$ & 0.745 & 0.178 & 0.177 & -0.268 & Reflect & 0.125 & $<0.001$ \\
\hline X.2.1.1 & -0.059 & 0.495 & 0.455 & -0.389 & Reflect & 0.141 & $<0.001$ \\
\hline $\mathrm{X} 2.2 .1$ & -0.342 & 0.705 & -0.71 & 0.54 & Reflect & 0.127 & $<0.001$ \\
\hline $\mathrm{X} 2.2 .2$ & -0.505 & 0.785 & -0.071 & 0.08 & Reflect & 0.122 & $<0.001$ \\
\hline $\mathrm{X} 2.3 .1$ & 0.368 & 0.558 & -0.133 & 0.257 & Reflect & 0.137 & $<0.001$ \\
\hline $\mathrm{X} 2.3 .2$ & -0.001 & 0.731 & -0.557 & 0.22 & Reflect & 0.126 & $<0.001$ \\
\hline $\mathrm{X} 2.4 .1$ & 0.431 & 0.65 & 0.185 & -0.268 & Reflect & 0.131 & $<0.001$ \\
\hline $\mathrm{X} 2.4 .2$ & 0.248 & 0.629 & 0.096 & -0.257 & Reflect & 0.132 & $<0.001$ \\
\hline $\mathrm{X} 2.5 .1$ & 0.129 & 0.707 & 0.769 & -0.348 & Reflect & 0.127 & $<0.001$ \\
\hline $\mathrm{X} 2.5 .2$ & -0.056 & 0.709 & 0.085 & 0.088 & Reflect & 0.127 & $<0.001$ \\
\hline Y1.1.1 & -0.236 & 0.289 & 0.707 & 0.099 & Reflect & 0.127 & $<0.001$ \\
\hline Y1.1.2 & -0.016 & 0.38 & 0.771 & 0.012 & Reflect & 0.123 & $<0.001$ \\
\hline Y1.1.3 & -0.048 & 0.637 & 0.813 & 0.165 & Reflect & 0.121 & $<0.001$ \\
\hline Y1.2.1 & 0.164 & 0.481 & 0.769 & 0.223 & Reflect & 0.123 & $<0.001$ \\
\hline Y1.2.2 & -0.186 & -0.552 & 0.451 & -0.355 & Reflect & 0.144 & 0.002 \\
\hline Y1.3.1 & 0.053 & -0.365 & 0.879 & -0.052 & Reflect & 0.117 & $<0.001$ \\
\hline Y1.3.2 & 0.165 & -0.504 & 0.887 & -0.123 & Reflect & 0.116 & $<0.001$ \\
\hline Y1.3.3 & -0.019 & -0.425 & 0.868 & -0.081 & Reflect & 0.118 & $<0.001$ \\
\hline Y2.1.1 & 0.047 & -0.081 & 0.638 & 0.829 & Reflect & 0.12 & $<0.001$ \\
\hline Y2.1.2 & -0.008 & -0.12 & 0.091 & 0.558 & Reflect & 0.137 & $<0.001$ \\
\hline Y2.2.1 & -0.637 & 0.098 & 0.047 & 0.65 & Reflect & 0.131 & $<0.001$ \\
\hline Y2.2.2 & -0.455 & -0.152 & 0.51 & 0.469 & Reflect & 0.143 & 0.001 \\
\hline Y2.3.1 & 0.435 & 0.177 & -0.61 & 0.837 & Reflect & 0.119 & $<0.001$ \\
\hline Y2.3.2 & 0.271 & -0.008 & -0.403 & 0.843 & Reflect & 0.119 & $<0.001$ \\
\hline
\end{tabular}


The value of cross loading for each indicator in the table above is still there which is worth when the cross-loading value between indicator and respective construct is higher than correlation with other construct. This means that this value has sufficient discriminant on the intended construct, which should be larger than the loading value with the other constructs.

Another method to view discriminant validity is to look at the square root value of average variance extracted (AVE). The recommended value is above 0.5 (Gaston in Yamin, 2011). Here are the values of AVE in this study:

Tabel 3:- Average Variance Extracted (AVE)

\begin{tabular}{|c|c|c|c|}
\hline Variables & AVE & $\begin{array}{c}\text { The Value of Intermediate } \\
\text { Correlation Quadrations }\end{array}$ & Conclusions \\
\hline Price & 0,381 & $0,346^{2}+0,03^{2}=0,1206$ & $\begin{array}{c}0,381>0,12 \\
\text { (diterima) }\end{array}$ \\
\hline Satisfaction & 0,608 & N/A & $\begin{array}{c}\text { AVE }>0,5 \\
\text { (diterima) }\end{array}$ \\
\hline Services & 0,408 & $0,477^{2}+0,25^{2}=0,29$ & $0,408>0,29$ \\
(diterima)
\end{tabular}

The table above gives AVE values above 0.5 for Consumer Satisfaction variables, Consumer Loyalty, and Product Quality. As for the variable Price and Service Quality has the lowest AVE value below 0.5. However, the square value of the latent constituent correlation is still below the existing AVE value. For the price variable, $(0.3462+$ $0.032)<0.439$. For service quality variables, $(0.4772+0.252)<0.483$. This explanation may occur because purchases made by consumers are long enough, so the problem of price and quality of service perceived by consumers at that time and the time of the survey becomes less valid.

Reliability test is done by looking at the composite reliability value of the indicator block that measures the construct. The result of composite reliability will show satisfactory value if above 0.7 . Here is the value of composite reliability at output:

Tabel 4:-Composite Reliability

\begin{tabular}{|l|c|}
\hline Variabel & Composite Reliability \\
\hline Price & 0.845 \\
\hline Satisfaction & 0.923 \\
\hline Services & 0.867 \\
\hline Loyalty & 0.856 \\
\hline
\end{tabular}

The table above shows that the value of composite reliability for all constructs is above 0.7 indicating that all constructs in the estimated model meet the discriminant validity criteria. The reliability test can also be reinforced with Cronbach's Alpha in which the SmartPLS Version 2 output gives the following results:

Tabel 5:-Cronbach's Alpha

\begin{tabular}{|l|l|}
\hline Variabel & Cronbachs Alpha \\
\hline Price & 0.793 \\
\hline Satisfaction & 0.902 \\
\hline Services & 0.826 \\
\hline Loyalty & 0.796 \\
\hline
\end{tabular}

The suggested value is above 0.5 and in the table above shows that Cronbach's Alpha value for all collisions is above 0.5 .

After the estimated model meets the Outer Model criteria, the next is a structural model test (Inner model). Here is the R-Square value of the construct: 
Tabel 6:-Tabel R-Square

\begin{tabular}{|l|l|}
\hline Variabel & R Square \\
\hline Price & N/A \\
\hline Satisfaction & 0.726 \\
\hline Services & N/A \\
\hline Loyalty & 0.465 \\
\hline
\end{tabular}

The table above gives a value of 0.726 for the Consumer Satisfaction construct which means that Price (X1) and Service Quality (X2) are able to explain the Consumer Satisfaction variance (Y1) of 72.6\%. R square value is also found in Consumer Loyalty influenced by Price, Quality of Service, and Consumer Satisfaction that is equal to 0,465 . The value of $\mathrm{R}$ square on customer satisfaction and loyalty is above the required minimum threshold value of 0.19 (Gaston in Yamin, 2011).

To validate the overall model, goodness of fit can be measured using Q-Square predictive relevance. Q-Square formula:

$\mathrm{Q} 2=1$ - (1 - R12) (1 - R22) ... (1- Rp2)

Where R12, R22 ... Rp2 is R-square the endogenous variable in the model.

Value Q2 = 1 - (1 - (R square Satisfaction) 2). (1 - (R square Loyalty) 2)

Therefore, the value of Q2 = 1 - (1 - 0.7262). (1 - 0.4652)

The value of the count Q2 $=0.629$; Means still higher than the required threshold value that is Q2>0. The Q-square value greater than 0 (zero) indicates that the model has predictive relevance value, while the Qsquare value less than 0 (zero) indicates that the model lacks predictive relevance (Gaston in Yamin, 2011).

Table 7:-Path Coefficients with (T-Values)

\begin{tabular}{|c|c|c|c|c|}
\hline & Path Coefficient & Standard Error & T-Statistic & P-Value \\
\hline Price $\rightarrow$ Satisfaction & 0.339 & 0.152 & 2.230 & 0.017 \\
\hline Satisfaction $\rightarrow$ Loyalty & 0.682 & 0.129 & 4.355 & $<0.001$ \\
\hline Service $\rightarrow$ Satisfaction & 0.588 & 0.135 & 5.287 & $<0.001$ \\
\hline
\end{tabular}

\section{Discussion:-}

In this study, the outcomes are all the same as the hypotheses made. Here is the explanation.

\section{Price Influence on Satisfaction}

Table 6 shows that the relationship between Price and Satisfaction is significant with T-statistics of 2,230 (>1,96). The value of path coeficient is positive that is equal to 0,339indicating that direction of relationship between Price and Consumer Satisfaction is positive. Thus the hypothesis H1 in this study which states that 'Price has significant effect on consumer satisfaction' is acceptable.

The results of this study prove that the Price significantly and positively affect the consumer satisfaction. Agree with Shi \& Smith (2012) that under normal circumstances, prices have a positive relationship to customer satisfaction. The intent of normal circumstances or not is based on the macroeconomic conditions occurring within a country. If in a state of crisis, high prices will still be purchased and provide satisfaction because the number of products available very small.

\section{Effect of Service Quality on Consumer Satisfaction}

Table 6 also shows that the relationship between Quality of Service and Consumer Satisfaction is significant with Tstatistics of 5,287 (> 1,96). The value of path coefficient is positive that is equal to 0.588 indicating that the direction of relationship between Quality of Service with Consumer Satisfaction is positive. Thus the hypothesis H2 in this study which states that 'Quality of service has significant effect on consumer satisfaction' is acceptable.

The results of this study prove that the excellent service quality needs to be done company to assist the products or services sold to consumers. Because if the company is not able to provide good service quality, then consumers will move to another company easily, because it will affect consumer satisfaction. This study supports the findings of 
Chabbra (2013) that the perception gap between the expectations and the reality of service quality that consumers perceive will affect satisfaction and the possibility of repeat purchase.

\section{The Effect of Consumer Satisfaction on Consumer Loyalty}

In addition, table 6 also shows that the relationship between Consumer Satisfaction and Consumer Loyalty is significant with T-statistics of 4,355 (> 1,96). The value of path coefficient is positive that is equal to 0,682 indicating that direction of relationship between Consumer Satisfaction with Consumer Loyalty is positive. Thus the hypothesis $\mathrm{H} 3$ in this study which states that 'Consumer satisfaction has a significant effect on consumer loyalty' is acceptable.

The results of this study prove that customer satisfaction tested repeatedly over a period of time will create loyalty in the end. Getting loyal customers is the hope of every company that wants to exist and experience long-term growth. This study is in line with Jayasankar \& Kumar (2012) who conducted empirical research and found that the main factor which is the most important impact of consumer satisfaction is consumer loyalty.

\section{Conclusion:-}

This research includes the influence of price and quality of service on customer satisfaction and loyalty. From the results of research conducted, it can be concluded several important things as follows:

1. Prices have a significant effect on customer satisfaction.

2. Quality of service has a significant effect on customer satisfaction.

3. Consumer satisfaction has a significant effect on consumer loyalty.

The conclusion of the research shows that there are similarities and differences between the previous research studied by the researchers compared to the results obtained.

The findings of this research will bring many implications such as for the theory as well as the practical implications. This implication needs to be followed up by various parties. The implications of the theory in the form of conceptual models of research and hypothesis verification need to be followed up by subsequent researchers and institutions of higher education. In addition, through this research also obtained practical implications for furniture entrepreneurs, especially DCK. Practical implications of policies to emphasize competitive prices, rather than quality of service.

Based on the findings available, here are the author's suggestions for subsequent research:

1. The population of this study is limited to furniture consumers in Surabaya, it is necessary to conduct further research with a wider scope or cross industry such as the same industry but regional or cross-industry scope within the same region. Thus it will explain the causal relationship between price, product quality, service quality, satisfaction, and customer loyalty on a wider scale.

2. The unit of analysis of this study is a mixture of consumer furniture for the needs of household and office, then the future needs to be further research on each type of consumer. Because household and office consumers have quite different needs preference for each other. 


\section{Bibliography:-}

1. Alptekinoglu, A., Corbett, C. (2008). Mass Customization Vs. Mass Production: Variety and Price Competition. Manufacturing \& Service Operation Management, Vol. 10 (2), p. 204-217.

2. Chhabra, N. (2013). Measurement of Consumers' Perception of Service Quality in Organized Retail Using Servqual Instrument. Management Dynamics, vol. 13 (1), p. 70-82

3. Ferdinand, A. (2010). Structural Equation Modeling Dalam Penelitian Manajemen (4th Edition ed.). Semarang: Badan Penerbit Universitas Diponegoro.

4. Hair Jr, J. F., Hult, G. T. M., Ringle, C., \& Sarstedt, M. (2014). A primer on partial least squares structural equation modeling (PLS-SEM). California: Sage Publications.

5. Hawkins, D., Mothersbaugh, D. (2011). Consumer Behavior: Building Marketing Strategy, 11th ed. New York: McGraw Hill.

6. Jayasankar, C., Kumar, V. (2012). Antecedents and Consequences of Customer Satisfaction in Food \& Grocery Retailing: An Empirical Analysis. Decision, Vol. 39 (3), p. 101 - 140.

7. Rawson, A., Duncan, E., Jones, C. The Truth about Customer Experience. Harvard Business Review, Sept 2013, p. 90-98.

8. Rust, R. \& Huang, M. (2012). Optimizing Service Productivity. Journal of Marketing, Vol. 76 (March 2012), p. 47-66.

9. Singh, A. (2013). Comparison of Service Quality, Customer Satisfaction and Behavioral intentions across the Various Formats (Supermarket, Hypermarket \& Departmental Store) in India. Business \& Economic Research, Vol. 3 (1), p. $344-355$.

10. Tetu, Y., Yuhlin, S., Kuihsu, T. (2013). The Impact of Brand Image and Customer Commitment on Loyalty: An Empirical Study of Automobile Sector. Information Management \& Business Review, Vol. 5 (4), p. 181 - 193.

11. Yamin. (2011). Regresi dan Korelasi dalam Genggaman Anda. Jakarta: Salemba Empat 